\title{
Inactivation of the von Hippel-Lindau tumour suppressor gene induces Neuromedin U expression in renal cancer cells
}

\author{
Sarah K Harten ${ }^{1,3^{*}}$, Miguel A Esteban², Deepa Shukla ${ }^{1}$, Margaret Ashcroft ${ }^{1}$ and Patrick H Maxwell ${ }^{1}$
}

\begin{abstract}
Background: 209000 new cases of renal carcinoma are diagnosed each year worldwide and new therapeutic targets are urgently required. The great majority of clear cell renal cancer involves inactivation of VHL, which acts as a gatekeeper tumour suppressor gene in renal epithelial cells. However how VHL exerts its tumour suppressor function remains unclear. A gene expression microarray comparing RCC10 renal cancer cells expressing either VHL or an empty vector was used to identify novel VHL regulated genes.

Findings: NMU (Neuromedin $U$ ) is a neuropeptide that has been implicated in energy homeostasis and tumour progression. Here we show for the first time that VHL loss-of-function results in dramatic upregulation of NMU expression in renal cancer cells. The effect of VHL inactivation was found to be mediated via activation of Hypoxia Inducible Factor (HIF). Exposure of VHL expressing RCC cells to either hypoxia or dimethyloxalylglycine resulted in HIF activation and increased NMU expression. Conversely, suppression of HIF in VHL defective RCC cells via siRNA of HIF- $\alpha$ subunits or expression of Type $2 \mathrm{C}$ mutant VHLs reduced NMU expression levels. We also show that renal cancer cells express a functional NMU receptor (NMUR1), and that NMU stimulates migration of renal cancer cells.

Conclusions: These findings suggest that NMU may act in an autocrine fashion, promoting progression of kidney cancer. Hypoxia and HIF expression are frequently observed in many non-renal cancers and are associated with a poor prognosis. Our study raises the possibility that HIF may also drive NMU expression in non-renal tumours.
\end{abstract}

\section{Findings}

Kidney cancer is responsible for 102000 deaths per year worldwide and prognosis is generally poor [1]. Clear cell renal cell carcinoma (CCRCC) is the commonest form of kidney cancer and the von Hippel-Lindau ( $V H L)$ tumour suppressor gene is mutated or inactivated in the vast majority of these tumours [2]. Mutations in $V H L$ also underlie the familial renal cancer syndrome VHL disease [3]. In addition to CCRCCs, patients with VHL disease are also predisposed to phaeochromocytomas, haemangioblastomas of the central nervous system and retina and cysts affecting a variety of organs including the kidney and pancreas [2]. Although much has been learnt about $V H L$ in recent years, its tumour suppressor function is still not fully understood.

\footnotetext{
* Correspondence: sarah.harten@gimr.edu.au

'Division of Medicine, University College London, London, UK

Full list of author information is available at the end of the article
}

There has been considerable success in developing new treatments for CCRCC that target aspects of the pathways related to loss of $V H L$ function [1]. As a strategy to identify further potential targets, we examined the effect of re-expressing $V H L$ in RCC10 renal cancer cells [4]. This cell background is attractive because reexpression of $V H L$ alone restores many aspects of normal epithelial cell behaviour, including formation of tight junctions $[5,6]$, adherens junctions $[7,8]$ and a primary cilium [9-11]. Three separate pools of RCC10 VHL defective CCRCC cells were transduced with retroviruses expressing wild-type $V H L$; in parallel three pools were transduced with an empty vector. A substantial number of genes showed highly significant differences in expression, including many known to be modulated by VHL status (Figure 1A).

The neuropeptide Neuromedin U (NMU) was selected as being of particular interest for the following reasons. First, it was amongst the most highly regulated genes
C Biomed Central

(c) 2011 Harten et al; licensee BioMed Central Ltd. This is an Open Access article distributed under the terms of the Creative Commons Attribution License (http://creativecommons.org/licenses/by/2.0), which permits unrestricted use, distribution, and reproduction in any medium, provided the original work is properly cited. 


\begin{tabular}{cccc} 
A & \multicolumn{3}{c}{} \\
\cline { 2 - 4 } & Gene & $\begin{array}{c}\text { Fold } \\
\text { regulation } \\
\text { VHL-/NHL+ }\end{array}$ & p value \\
\hline PHD3 & $\uparrow 10.87$ & 0.0022 \\
\hline NMU & $\uparrow 8.00$ & $<0.0001$ \\
\hline SLC2A3 & $\uparrow 6.76$ & 0.0005 \\
SYT13 & $\uparrow 6.37$ & 0.0060 \\
BNIP3 & $\uparrow 5.26$ & $<0.0001$ \\
\hline CRYAB & $\downarrow 9.26$ & 0.0084 \\
IFI44L & $\downarrow 5.59$ & 0.0456 \\
ITGB6 & $\downarrow 5.29$ & 0.0013 \\
KLH 13 & $\downarrow 4.69$ & 0.0022 \\
ASS & $\downarrow 4.37$ & 0.0054 \\
\hline
\end{tabular}
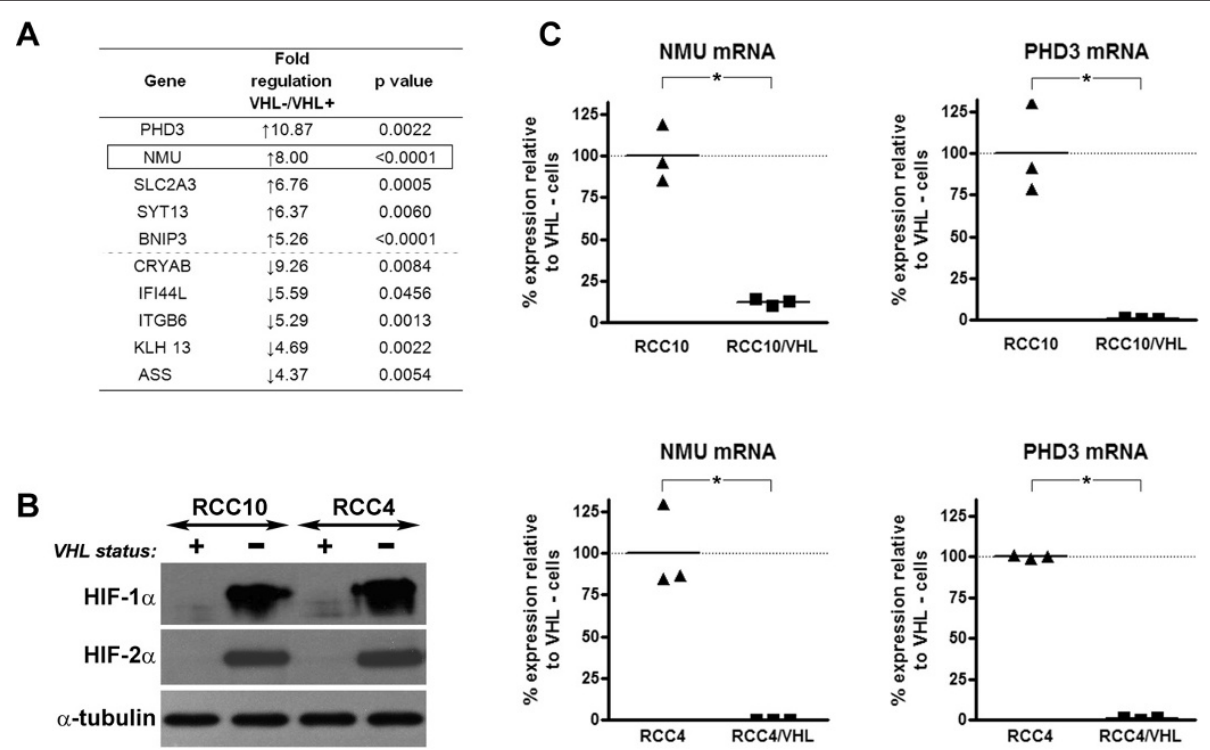

Figure 1 VHL regulates expression of Neuromedin U. A) RCC10 retroviral cell pools infected with empty vector or expressing wild-type VHL were prepared as described previously [7]. Cells were cultured for 48 hours and RNA expression analysed using an Affymetrix U133 Plus 2.0 human gene expression array. Microarray analysis identified differentially expressed genes by comparing expression levels in VHL defective cells to expression in VHL expressing cells. The five most highly upregulated and down-regulated genes, including NMU are listed in 1a. B) Protein lysates were prepared from VHL defective RCC10 and RCC4 cell lines and sub-lines stably expressing VHL and samples run on a SDS Page gel. Membranes were probed with HIF-1 $\alpha$ (BD, San Diego, CA), HIF-2 $\alpha$ (Novus Biologicals, Littleton, CO) and $\alpha$-tubulin (Sigma, St. Louis, MO). In the absence of VHL both HIF-1 $\alpha$ and HIF-2 $\alpha$ are clearly detected, however in the presence of VHL levels of both HIF- $1 \alpha$ and HIF-2 $\alpha$ are suppressed. Equal levels of $\alpha$-tubulin confirm equivalent loading. C) Real-time RT PCR analysis for NMU and the HIF target gene PHD3 was performed using SYBR-Green PCR Master Mix (Abgene, Epsom, United Kingdom). Data presented here has been normalised to expression of $\beta$-actin. Cell lines expressing VHL show marked suppression of NMU and PHD3 compared to VHL defective cell lines $\left({ }^{*} \mathrm{P}<0.01\right.$, using student's T test). (Primers: NMU For: 5'-CCTCAAGGATTACAGCCTG-3', NMU Rev: 5'-GTTCCTGAGGCTTTGGTAG-3; PHD3 For F 5'-GATGCTGAAGAAAGGGC-3', PHD3 Rev R 5'CTGGCAAAGAGAGTATCTG-3'; $\beta$-actin For 5'-CCCAGAGCAAGAGAGAGG-3', $\beta$-actin Rev 5'-GTCCAGACGCAGGATG-3').

and has not previously been identified as modulated by $V H L$. Second, it acts on two identified G-protein coupled receptors making it potentially pharmacologically tractable [12]. Third, it has been implicated in autocrine growth and epithelial to mesenchymal transition in cancer [13]. Fourth, as a secreted peptide NMU may offer potential as a circulating or urinary biomarker in CCRCC. Recently Ketterer et al. showed that serum levels of NMU decrease following pancreas resection of pancreatic cancer patients [14].

NMU is a potent neuropeptide which was originally discovered in the 1980's. In humans $N M U$ gives rise to a biologically active icosapentapeptide (NMU-25); function is dependent on a highly conserved $\mathrm{C}$ terminal sequence which is subject to enzymatic amidation. Several biological functions have been ascribed to NMU including regulation of smooth muscle contraction, blood pressure and local blood flow, ion transport in the gut, stress responses, gastric acid secretion, nociception and feeding behaviour $[12,15,16]$.

To confirm the effect of VHL status on NMU expression that we observed on microarray analysis of retrovirally transduced pools of RCC10 cells, we next examined NMU expression in RCC10 cells and a subline stably expressing wild-type $V H L(\mathrm{RCC} 10 / V H L)$. We also examined a second $V H L$ defective renal cancer cell line and subline expressing VHL derived from a different patient (RCC4 and RCC4/VHL). As expected, VHL suppressed HIF- $\alpha$ protein levels (Figure 1B) and mRNA expression of the HIF target gene PHD3 (Figure 1C) in both cell backgrounds. Real time RT-PCR analysis showed NMU mRNA expression was markedly increased in the absence of functioning VHL in both RCC10 and RCC4 cells (Figure 1C).

Several different biochemical functions have been reported for VHL including regulation of microtubule stability, cell differentiation, cell motility, extracellular matrix assembly, JunB and atypical isoforms of protein kinase $C$ [2]. However the most extensively studied function of VHL is regulation of HIF [17]. HIF is comprised of a constitutively active $\beta$ subunit and an oxygen-regulated $\alpha$ subunit. In the presence of oxygen the $\alpha$-subunit is hydroxylated by a group of prolyl hydroxylase domain (PHD) enzymes, leading to capture by VHL, ubiquitination and proteosomal destruction [17-19]. In hypoxia (or if $V H L$ is inactivated) HIF $\alpha$ is 
stabilised. HIF is a master regulator of oxygen homeostasis and drives the transcriptional upregulation of $>100$ genes involved in processes such as glucose transport, glycolysis and angiogenesis, which collectively allow the adaption of the cells, tissues and organisms to low oxygenation $[2,17,18]$.

To investigate whether activation of HIF mediates the high expression of NMU we exposed RCC10 cells stably expressing $V H L$ to hypoxia as a means of activating HIF. Exposure of RCC10/ VHL cells to hypoxia for 48 hrs resulted in a significant increase in mRNA levels of NMU compared to normoxic cultures (Figure 2). In a second approach, we activated HIF in the presence of $V H L$, using dimethyloxalylglycine (DMOG), a cell permeable 2-oxyglutarate-dependent dioxygenase inhibitor which inhibits the PHD enzymes. Treatment with DMOG resulted in a striking induction of both $N M U$ mRNA compared to untreated cells (Figure 2). These results would be consistent with HIF activation mediating increased NMU expression in $V H L$ defective CCRCC cells.

To further investigate the ability of HIF to mediate NMU expression we studied the effect of $V H L$ missense mutants, L188V and V84L. These single amino acid substitutions are associated clinically with phaeochromocytoma, but not with other tumours (type $2 \mathrm{C} \mathrm{VHL}$ disease) and retain the ability to regulate HIF [20]. Analysis by real time RT-PCR showed a marked mRNA suppression of NMU in cell pools expressing either wild type $V H L$ or type $2 \mathrm{C}$ mutant $V H L$, in both $\mathrm{RCC} 10$ and RCC4 cells (Figure 3A). The concordance between the ability of VHL mutants to suppress both HIF and NMU levels supports the notion that HIF activation underlies the VHL defective phenotype. Next we used a direct genetic approach to determine the role of HIF. RCC10 and RCC4 VHL defective cells were transfected with previously validated siRNAs to selectively suppress either HIF- $1 \alpha$ or HIF- $2 \alpha$, or with a control siRNA. Knock-down of either HIF- $\alpha$ isoform resulted in decreased expression of NMU in both cell backgrounds (Figure 3B). Taken together these findings provide strong evidence that $V H L$ regulates NMU expression in renal cancer cells via HIF.

Next we asked whether NMU contains a HIF binding site, known as a hypoxia response element (HRE). A 12 $\mathrm{kb}$ segment upstream of the transcriptional start site and the first intron $(3 \mathrm{~kb})$ were analysed. Although this region contains several candidate HREs, none were found to be responsive to HIF activation as assessed by increased luciferase reporter activity. There are three possible explanations for this. First, the region may contain a functional HRE but the transfection assays did not provide requisite conditions to detect this. This possibility is lessened because we used different approaches to activate HIF (DMOG or co-transfection with a plasmid expressing constitutively active HIF), different cell

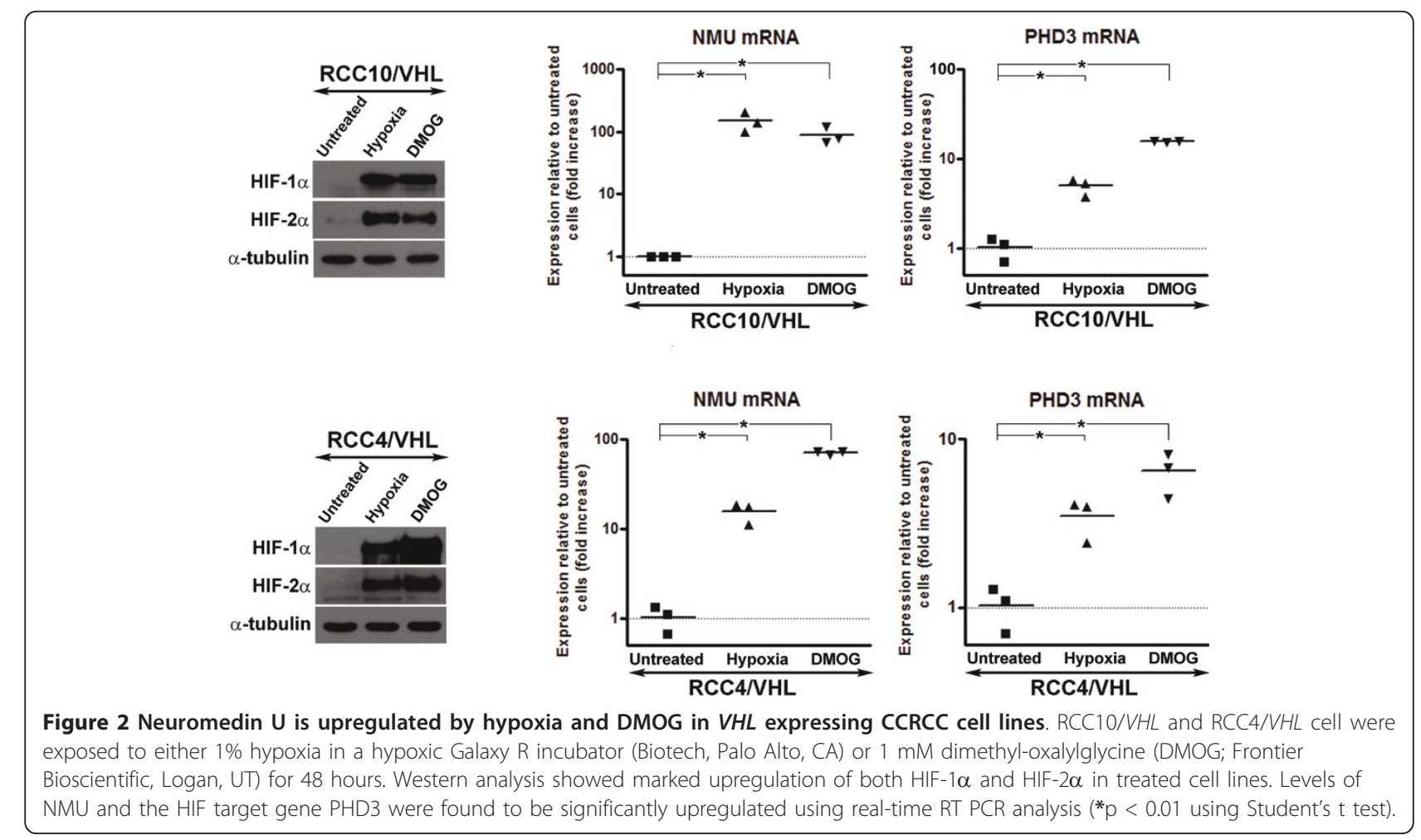




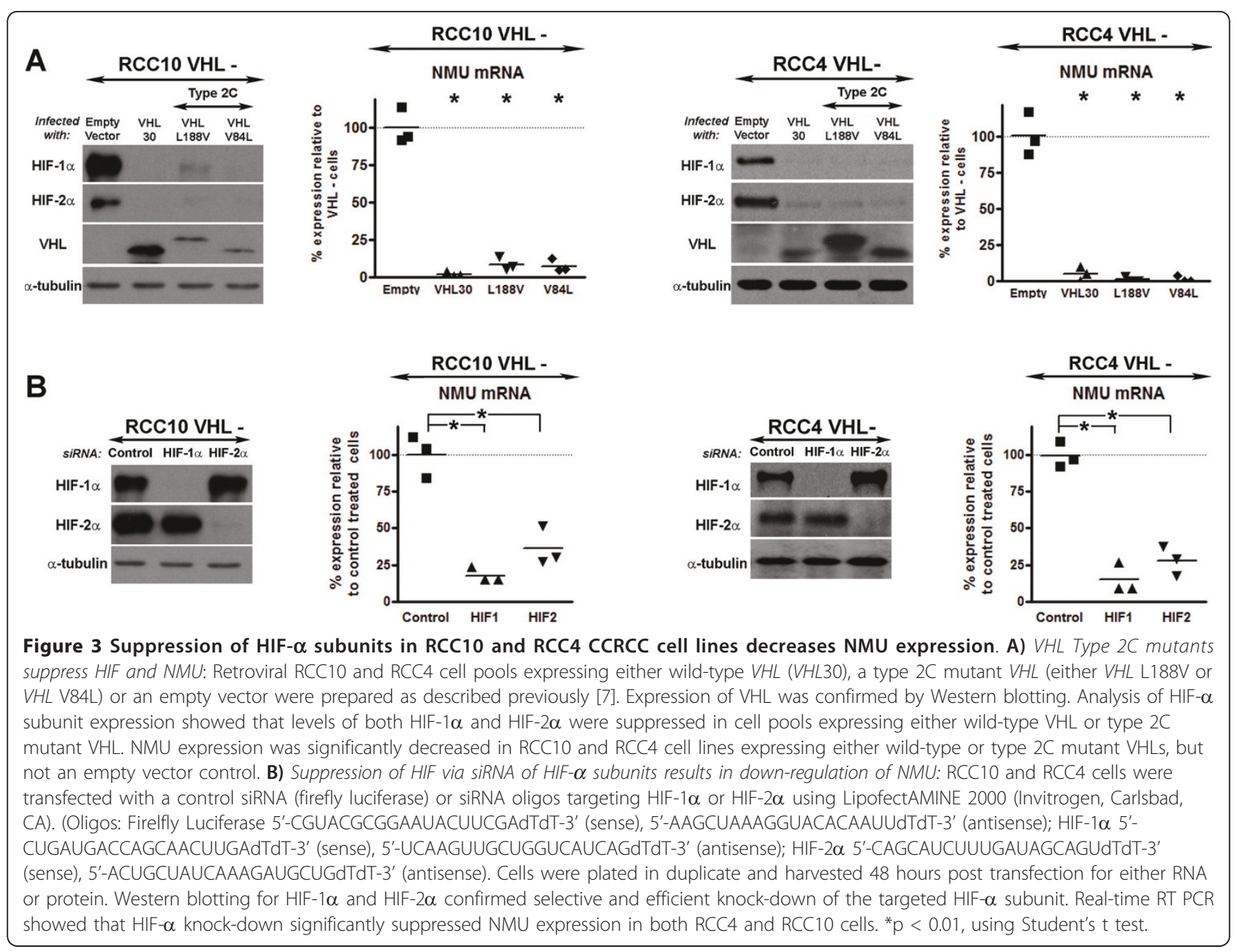

lines, and all experiments were accompanied by controls using an HRE which confirmed a high amplitude HIF response. Second, there may be an HRE which lies outside this region; a precedent for this is the prototypical HRE which actually lies 3' to the EPO gene [21]. Third, the effect of HIF may be indirect.

$\mathrm{NMU}$ is believed to act mainly in a paracrine fashion, and autocrine signalling has been suggested in several cancer settings [13]. To determine whether renal cancer cells might respond to NMU we first examined expression of the receptors NMUR1 and NMUR2. Western analysis showed that NMUR1 was expressed in both the RCC4 and RCC10 cell backgrounds and that there was no substantial effect of $V H L$ status on expression levels (Figure 4A). Expression of NMUR2 was not detected (data not shown). Previous studies have reported that NMU receptor binding triggers the mobilisation of intracellular calcium [13]. Renal cancer cells and sublines expressing $V H L$ (RCC10, RCC4, RCC10/VHL, $\mathrm{RCC} 4 / \mathrm{VHL}$ ) were loaded with a calcium sensitive fluorescent dye prior to treatment with exogenous NMU peptide. Addition of NMU caused a sharp calcium influx in all cell lines, regardless of $V H L$ status, whereas addition of vehicle alone caused no significant change. A representative FLIPR trace is shown in Figure 4B. Given that these experiments show that an NMU response pathway is present in renal cancer cells, we next investigated the potential functional role of NMU in these cells.

Proliferation and tissue invasion and metastasis are two hallmarks of cancer that have been associated with NMU expression in other cell types [14,22,23]. First we tested the effect of NMU on proliferation. Exogenous NMU peptide was added to RCC10/VHL cells; no effect on cell growth was observed (data not shown). Next we tested the ability of NMU to promote migration and invasion of renal cancer cells. RCC10/VHL retroviral cell pools expressing either an empty vector or NMU were prepared and NMU expression was verified by real-time RT-PCR. To assess migration, cells were serum starved for 24 hours, fluorescently labelled and then plated onto the upper section of a transwell chamber in serum free 


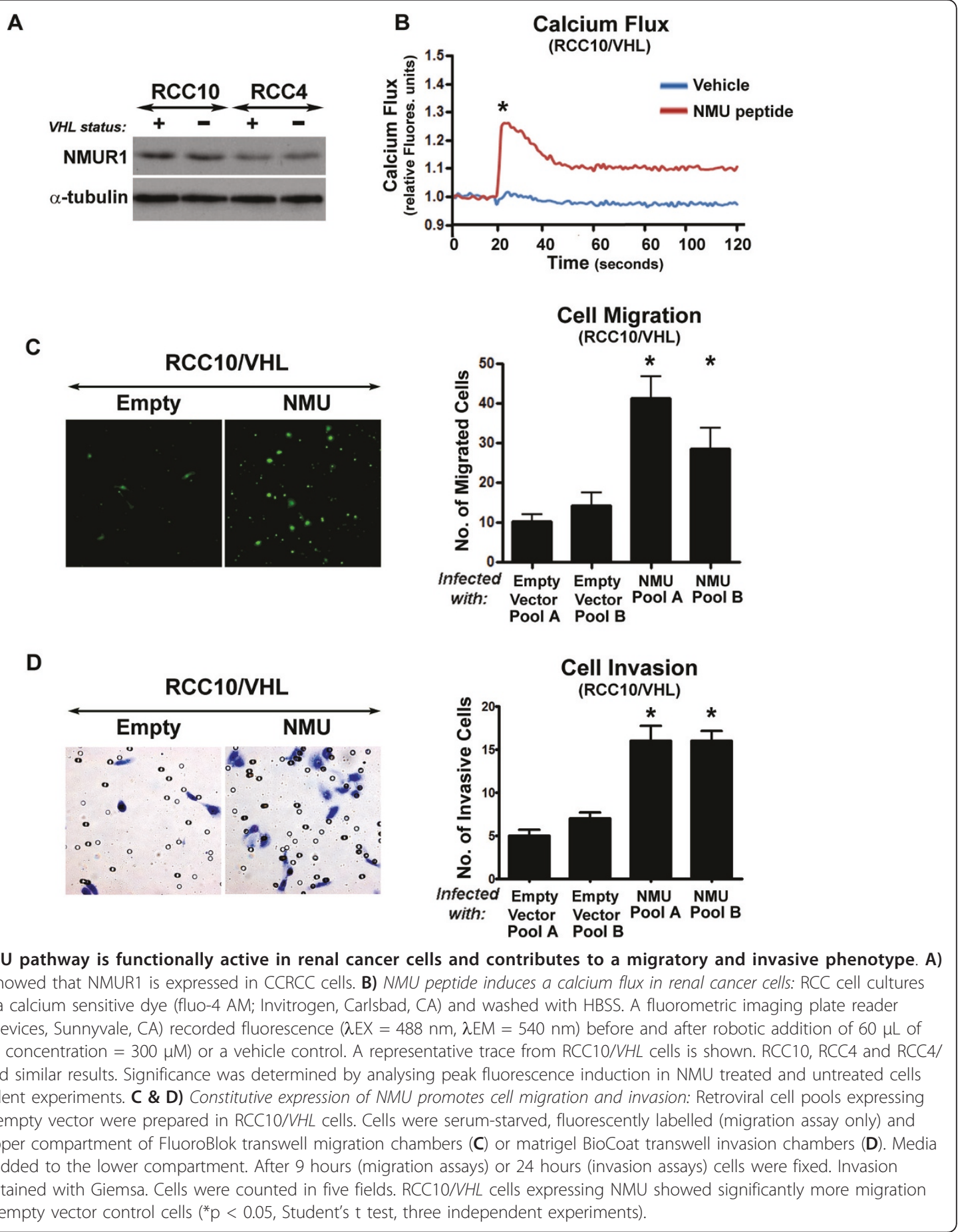

media. The number of cells that migrated through the membrane was recorded. Invasion assays were performed by plating serum-starved cells onto matrigel coated transwell chambers in serum free media. After 24 hours, cells were removed from the top layer and invasive cells on the bottom layer were fixed, stained with Giemsa and counted. Data from three independent experiments and representative photomicrographs are shown in Figure 4C and 4D. Thus expression of NMU was found to significantly enhance both cell migration and invasion of RCC10/VHL cells.

Next, we searched the Gene Expression Omnibus database (GEO, http://www.ncbi.nlm.nih.gov/geo/) for publicly available microarray datasets comparing gene 
expression in normal human kidney tissues to CCRCC tissues. Three relevant datasets were identified. Analysis of data from Gumz et al. showed a $>2$ fold upregulation of NMU in 5/10 pairs of matched normal kidney and tumour tissue from patients with sporadic CCRCCs (Additional File 1a) [24]. Analysis of two larger, independent datasets comparing unmatched normal kidney and CCRCC tissues, GSE15641 and GSE14994, also showed $>2$ fold upregulation of NMU in $46.9 \%$ and $11.9 \%$ of CCRCCs, respectively, compared to the mean expression in normal kidney (Additional File 1b and 1c) $[25,26]$. These results are consistent with NMU expression being substantially increased in a subset of human CCRCCs.

Loss of functional $V H L$ has previously been shown to enhance migration and invasion [27]. Here we demonstrate an autocrine NMU pathway in renal cancer cells that likely contributes to promoting migration of $V H L$ expressing cells. This adds to evidence for a role of $\mathrm{NMU}$ in diverse cancers including bladder carcinoma [22], ovarian carcinoma [28], lung cancer [23] and acute myeloid leukaemia [13]. It also raises the possibility that HIF activation, for example at altitude, could increase physiological NMU signalling in the brain causing loss of appetite.

\section{Additional material}

Additional File 1: External data sets show a subset of clear cell renal carcinomas with upregulation of NMU compared to normal kidney. Publicly available microarray datasets comparing expression in normal human kidney tissue to CCRCC tissues were interrogated for NMU expression. A) A scatter plot showing NMU expression in matched normal and tumour tissue samples from patients with sporadic CCRCCs (GDS2880; [24]). 5/10 pairs show > 2 fold upregulation of NMU (data points shown in red). B), C) Scatterplots show fold upregulation of NMU in normal kidney and CCRCC tissue samples compared to the mean expression level detected in normal kidneys in two external datasets, GSE15641 [26] and GSE14994 [25]. Data points in red show > 2 fold upregulation (GSE15641, 15/32 (46.9\%) CCRCC samples show $>2$ fold upregulation; GSE14994, 7/59 (11.9\%) of CCRCC samples show >2 fold upregulation). Normalised data available from GEO was used for all analyses.

\section{List of abbreviations}

CCRCC: clear cell renal cell carcinoma; FLIPR: fluorometric imaging plate reader; GEO: Gene Expression Omnibus; HIF: hypoxia-inducible factor; HRE: hypoxia response element; DMOG: dimethyl-oxalylglycine; NMU:

Neuromedin U; PHD: prolyl hydroxylase domain; VHL: von Hippel-Lindau.

\section{Acknowledgements}

We thank Dr Evon Poon for assistance with the cell migration experiments and Mr Sam Ranasinghe for assistance with the calcium flux experiments. This work was supported by a Cancer Research UK grant to P.H.M. and M.A. E. and by the EU framework 7 project Metoxia.

\section{Author details}

${ }^{1}$ Division of Medicine, University College London, London, UK. ${ }^{2}$ South China Institute of Stem Cell Biology and Regenerative Medicine, Guangzhou
Institute of Biomedicine and Health, Chinese Academy of Sciences, Guangzhou 510663, China. ${ }^{3}$ ACRF Centre for Cancer Epigenetics, Queensland Institute of Medical Research, Herston Road, Brisbane, Australia.

\section{Authors' contributions}

SKH prepared the retroviral expression plasmid encoding NMU and retroviral cell pools used throughout the study, produced most of the experimental data and drafted the initial manuscript. MAE contributed to the study design and prepared retroviral vectors encoding VHL type $2 \mathrm{C}$ mutants. DS assisted with addressing reviewer comments. MA provided input on experimental strategy and study design. PHM co-ordinated the study and wrote the final manuscript. All authors contributed to study design, analysis and interpretation of data and read and approved the final manuscript.

\section{Competing interests}

SKH, MA, DS and MAE declare that they have no competing interests. PHM is a Director and shareholder in ReOx Ltd.

Received: 4 January 2011 Accepted: 26 July 2011

Published: 26 July 2011

\section{References}

1. Rini BI, Campbell SC, Escudier B: Renal cell carcinoma. Lancet 2009, 373:1119-1132.

2. Kaelin WG Jr: Molecular basis of the VHL hereditary cancer syndrome. Nat Rev Cancer 2002, 2:673-682

3. Latif F, Tory K, Gnarra J, Yao M, Duh FM, Orcutt ML, Stackhouse T, Kuzmin I, Modi W, Geil L, Schmidt L, Zhou F, Li H, Hui Wei M, Chen F, Glenn G, Choyke P, Walther MM, Weng Y, Duan DR, Dean M, Glavačc D, Richards FM, Crossey PA, Ferguson-Smith MA, Le Paslier D, Chumakov I, Cohen D, Chinault AC, Maher ER, Linehan WM, et al: Identification of the von Hippel-Lindau disease tumor suppressor gene. Science 1993, 260:1317-1320.

4. Harten SK, Esteban MA, Maxwell PH: Identification of novel VHL regulated genes by transcriptomic analysis of RCC10 renal carcinoma cells. Adv Enzyme Regul 2009, 49:43-52.

5. Calzada MJ, Esteban MA, Feijoo-Cuaresma M, Castellanos MC, NaranjoSuarez S, Temes E, Mendez F, Yanez-Mo M, Ohh M, Landazuri MO: von Hippel-Lindau tumor suppressor protein regulates the assembly of intercellular junctions in renal cancer cells through hypoxia-inducible factor-independent mechanisms. Cancer Res 2006, 66:1553-1560.

6. Harten SK, Deepa S, Barod R, Hergovich A, Balda M, Matter K, Esteban MA Maxwell PH: Regulation of renal epithelial tight junctions by the VHL tumor suppressor gene involves repression of occludin and claudin 1 and is independent of E-cadherin. Mol Biol Cell 2009, 20:13.

7. Esteban MA, Tran MG, Harten SK, Hill P, Castellanos MC, Chandra A, Raval R, O'Brien T S, Maxwell PH: Regulation of E-cadherin expression by VHL and hypoxia-inducible factor. Cancer Res 2006, 66:3567-3575.

8. Krishnamachary B, Zagzag D, Nagasawa H, Rainey K, Okuyama H, Baek JH, Semenza GL: Hypoxia-inducible factor-1-dependent repression of Ecadherin in von Hippel-Lindau tumor suppressor-null renal cell carcinoma mediated by TCF3, ZFHX1A, and ZFHX1B. Cancer Res 2006, 66:2725-2731.

9. Esteban MA, Harten SK, Tran MG, Maxwell PH: Formation of primary cilia in the renal epithelium is regulated by the von Hippel-Lindau tumor suppressor protein. J Am Soc Nephrol 2006, 17:1801-1806.

10. Thoma CR, Frew IJ, Hoerner CR, Montani M, Moch H, Krek W: pVHL and GSK3beta are components of a primary cilium-maintenance signalling network. Nat Cell Biol 2007, 9:588-595.

11. Lutz MS, Burk RD: Primary cilium formation requires von hippel-lindau gene function in renal-derived cells. Cancer Res 2006, 66:6903-6907.

12. Brighton PJ, Szekeres PG, Willars GB: Neuromedin U and its receptors: structure, function, and physiological roles. Pharmacol Rev 2004, 56:231-248.

13. Shetzline SE, Rallapalli R, Dowd K, Zou S, Nakata Y, Swider CR, Kalota A, Choi JK, Gewirtz AM: Neuromedin U: a Myb-regulated autocrine growth factor for human myeloid leukemias. Blood 2004, 104:1833-1840.

14. Ketterer K, Kong B, Frank D, Giese NA, Bauer A, Hoheisel J, Korc M, Kleeff J, Michalski CW, Friess $\mathrm{H}$ : Neuromedin $\mathrm{U}$ is overexpressed in pancreatic cancer and increases invasiveness via the hepatocyte growth factor cMet pathway. Cancer Lett 2009, 277:72-81. 
15. Hanada R, Teranishi H, Pearson JT, Kurokawa M, Hosoda H, Fukushima N, Fukue $Y$, Serino R, Fujihara H, Ueta $Y$, Ikawa M, Okabe M, Murakami N, Shirai M, Yoshimatsu H, Kangawa K, Kojima M: Neuromedin $U$ has a novel anorexigenic effect independent of the leptin signaling pathway. Nat Med 2004, 10:1067-1073.

16. Minamino N, Kangawa K, Matsuo H: Neuromedin U-8 and U-25: novel uterus stimulating and hypertensive peptides identified in porcine spinal cord. Biochem Biophys Res Commun 1985, 130:1078-1085.

17. Maxwell PH, Wiesener MS, Chang GW, Clifford SC, Vaux EC, Cockman ME, Wykoff CC, Pugh CW, Maher ER, Ratcliffe PJ: The tumour suppressor protein VHL targets hypoxia-inducible factors for oxygen-dependent proteolysis. Nature 1999, 399:271-275.

18. Semenza GL: Defining the role of hypoxia-inducible factor 1 in cancer biology and therapeutics. Oncogene 29:625-634

19. Kibel A, lliopoulos O, DeCaprio JA, Kaelin WG Jr: Binding of the von Hippel-Lindau tumor suppressor protein to Elongin B and C. Science 1995, 269:1444-1446.

20. Hoffman MA, Ohh M, Yang H, Klco JM, Ivan M, Kaelin WG Jr: von HippelLindau protein mutants linked to type $2 \mathrm{C}$ VHL disease preserve the ability to downregulate HIF. Hum Mol Genet 2001, 10:1019-1027.

21. Semenza GL, Wang GL: A nuclear factor induced by hypoxia via de novo protein synthesis binds to the human erythropoietin gene enhancer at a site required for transcriptional activation. Mol Cell Biol 1992, 12:5447-5454.

22. Wu Y, McRoberts K, Berr SS, Frierson HF, Conaway M, Theodorescu D: Neuromedin $\mathrm{U}$ is regulated by the metastasis suppressor RhoGDI2 and is a novel promoter of tumor formation, lung metastasis and cancer cachexia. Oncogene 2007, 26:765-773.

23. Takahashi K, Furukawa C, Takano A, Ishikawa N, Kato T, Hayama S, Suzuki C, Yasui W, Inai K, Sone S, Ito T, Nishimura H, Tsuchiya E, Nakamura Y, Daigo Y: The neuromedin U-growth hormone secretagogue receptor $1 \mathrm{~b} /$ neurotensin receptor 1 oncogenic signaling pathway as a therapeutic target for lung cancer. Cancer Res 2006, 66:9408-9419.

24. Gumz ML, Zou H, Kreinest PA, Childs AC, Belmonte LS, LeGrand SN, Wu K, Luxon BA, Sinha M, Parker AS, Sun LZ, Ahlquist DA, Wood CG, Copland JA: Secreted frizzled-related protein 1 loss contributes to tumor phenotype of clear cell renal cell carcinoma. Clin Cancer Res 2007, 13:4740-4749.

25. Beroukhim R, Brunet JP, Di Napoli A, Mertz KD, Seeley A, Pires MM, Linhart D, Worrell RA, Moch H, Rubin MA, Sellers WR, Meyerson M, Linehan WM, Kaelin WG Jr, Signoretti S: Patterns of gene expression and copy-number alterations in von-hippel lindau disease-associated and sporadic clear cell carcinoma of the kidney. Cancer Res 2009, 69:4674-4681.

26. Jones J, Otu H, Spentzos D, Kolia S, Inan M, Beecken WD, Fellbaum C, Gu X, Joseph M, Pantuck AJ, Jonas D, Libermann TA: Gene signatures of progression and metastasis in renal cell cancer. Clin Cancer Res 2005, 11:5730-5739.

27. Zia MK, Rmali KA, Watkins G, Mansel RE, Jiang WG: The expression of the von Hippel-Lindau gene product and its impact on invasiveness of human breast cancer cells. Int J Mol Med 2007, 20:605-611.

28. Euer NI, Kaul S, Deissler H, Mobus VJ, Zeillinger R, Weidle UH: Identification of L1CAM, Jagged2 and Neuromedin $\mathrm{U}$ as ovarian cancer-associated antigens. Oncol Rep 2005, 13:375-387.

doi:10.1186/1476-4598-10-89

Cite this article as: Harten et al:: Inactivation of the von Hippel-Lindau tumour suppressor gene induces Neuromedin $\mathrm{U}$ expression in renal cancer cells. Molecular Cancer 2011 10:89.

\section{Submit your next manuscript to BioMed Central and take full advantage of:}

- Convenient online submission

- Thorough peer review

- No space constraints or color figure charges

- Immediate publication on acceptance

- Inclusion in PubMed, CAS, Scopus and Google Scholar

- Research which is freely available for redistribution

Submit your manuscript at www.biomedcentral.com/submit
Biomed Central 